\title{
Penggunaan ILP untuk Vehicle Routing Problem pada Penjadwalan Distribusi Barang
}

\section{Use of ILP for Vehicle Routing Problems in Scheduling Goods Distribution}

\author{
Ardana Putri Farahdiansari, S.T., M.T. ${ }^{1 *}$, Muhammad Budi R.W, S.T., M.T. ${ }^{2}$ \\ 1,2 Jurusan Teknik Industri, Fakultas Sains dan Teknologi, Universitas Bojonegoro \\ Jl. Lettu Suyitno no. 02 Bojonegoro \\ Email: putri.faradian@gmail.com, rmuhammadbudi@gmail.com
}

\begin{abstract}
ABSTRAK
Disribusi merupakan salah satu aspek penting dalam proses sampainya produk ke tangan konsumen. Dalam dunia industri, ketepatan waktu dan efisiensi biaya distribusi menjadi salah satu tolak ukur keberhasilan pasar karena keberhasilan sampainya produk ke konsumen merupakan kunci supaya produk dapat dijual dengan baik dan memberikan profit pada perusahaan. Proses distribusi harus melewati beberapa titik lokasi pasar sekaligus dalam satu satuan waktu, maka penjadwalan distribusi harus dirancang agar proses distribusi dapat berjalan secara optimal dan efisien. Penelitian ini dilakukan di sebuah perusahaan distribusi bahan makanan kemasan yang harus mengirimkan barang rutin setiap hari dan dalam sehari harus mencapai beberapa pasar sekaligus. Jumlah kendaraan pengiriman terbatas sehingga penjadwalan harus optimal supaya semua pasar dapat terpasok produk dalam batasan waktu yang tersedia. Konsep Vehicle Routing Problem merupakan konsep yang identic dengan permasalahan yang terjadi pada penelitian. Penggunaan model algoritma Integer Linear Proggraming dapat digunakan untuk menerjemahkan permasalahan ini ke dalam perhitungan matematis. Software add-ins Solver pada Microsoft Excel menjadi tool sederhana namun mampu digunakan untuk menyelesaikan optimasi model. Hasil dalam penelitian adalah perusahaan dapat memiliki tool yang mampu membuat penjadwalan distribusi menjadi akurat dan otomatis serta menghasilkan biaya yang efisien.
\end{abstract}

Kata Kunci: distribusi, penjadwalan, pasar, vehicle routing problem, integer linear proggraming

\begin{abstract}
Distribution is one of the important aspects in the process of getting the product into the hands of consumers. In the industrial world, punctuality and efficiency of distribution costs are one of the benchmarks for market success because the successful delivery of products to consumers is the key so that products can be sold well and provide profit to the company. The distribution process must pass through several points of market locations at once in one unit of time, so distribution scheduling must be designed so that the distribution process can run optimally and efficiently. This research was conducted in a packaged food distribution company that has to deliver goods routinely every day and in a day it has to reach several markets at once. The number of delivery vehicles is limited, so scheduling must be optimal so that all markets can be supplied with products within the time limit available. The concept of Vehicle Routing Problem is a concept that is identical to the problems that occur in research. The use of the Integer Linear Programming algorithm model can be used to translate this problem into mathematical calculations. The Solver add-ins software in Microsoft Excel is a simple but capable tool to complete model optimization. The result of this research is that companies can have tools that can make distribution scheduling accurate and automatic and produce efficient costs.
\end{abstract}

Keywords: distribution, scheduling, market, vehicle routing problem, integer linear programming.

\section{Pendahuluan}

Suatu perusahaan distribusi bahan makanan mentah kemasan di kota Bojonegoro, Jawa Timur memiliki target untuk memasok barang dari produsen ke 15 (lima belas) kecamatan. Dengan jumlah 5 (lima) hari kerja untuk pengiriman yaitu Senin s.d Jumat, maka setiap harinya dilakukan penjadwalan pengiriman. Pada kondisi sebelumnya penjadwalan dilakukan oleh Kepala Divisi Pengiriman dengan memprioritaskan jumlah pemesanan terbanyak atau melihat jarak pasar (kecamatan) yang berdekatan. Namun penjadwalan dilakukan dengan perhitungan manual sehingga 
diperkirakan terkadang terdapat ketidakefisiensian dalam penjadwalan.

Kondisi tersebut merupakan jenis Vehicle Routing Problem yang dapat diselesaikan dengan algoritma seperti Integer Linear Programming (Pop et al. 2011). Dengan memodelkan masalah ke dalam bentuk ILP, maka dapat menajdi tool sederhana yang dapat membantu proses penjadwalan distributor lebih cepat dan otomatis. Diharapkan penjadwalan ini yang mampu menentukan rute pengiriman harian sesuai jumlah pesanan produk dan batasan kapasitas kendaraan pengiriman. Penjadwalan juga harus mampu memenuhi target untuk pengiriman ke semua titik atau lokasi pasar dalam waktu seminggu hari kerja, namun tetap efisien dari segi biaya distribusi. Dengan tercapainya tujuan tersebut, maka penelitian akan mampu mengoptimalkan dan menggantikan metode manual dalam penjadwalan distribusi

\section{Metode Penelitian}

Adapun metode yang digunakan dalam penelitian dan pengumpulan data dalam penelitian ini adalah sebagai berikut:

\section{Studi Pustaka}

Pada penelitian ini bidang yang diperlukan untuk dipelajari adalah bagaimana fungsi distribusi dalam manajemen rantai pasok dan konsep Vehicle Routing Problem yang digunakan untuk memodelkan permasalahan.

Distribusi memiliki arti atau merujuk pada kegiatan penyaluran, baik berupa pembagian atau pengiriman, kepada beberapa orang maupun beberapa tempat (Fisher, 1995). Dalam perspektif bisnis, distribusi merujuk pada upaya memperlancar dan mempermudah proses penyampaian atau penyaluran barang dan jasa dari produsen ke konsumen Salah satu faktor kunci untuk mengoptimalkan supply chain adalah dengan menciptakan alur informasi yang bergerak secara mudah dan akurat diantara jaringan atau mata rantai tersebut, dan pergerakan barang yang efektif dan efisien yang menghasilkan kepuasan maksimal pada para pelanggan (Indrajit dan Djokopranoto, 2003). Dengan tercapainya koordinasi dari rantai supply perusahaan, maka tiap channel dari rantai supply perusahaan tidak akan mengalami kekurangan barang juga tidak kelebihan barang terlalu banyak. Menurut Indrajit dan Djokopranoto (2003) dalam supply chain ada beberapa pemain utama yang merupakan perusahaan-perusahaan yang mempunyai kepentingan didalam arus barang, para pemain utama itu adalah:
1. Supplier
2. Manufacturer
3. Distributor / wholesaler
4. Retail outlets
5. Customers

Maka pada rantai pasok dengan rantai : Supplier - Manufacturer - Distributor - Retail Outlet -
Customer, posisi distributor adalah cukup penting karena barang dari pabrik melalui gudangnya akan disalurkan dahulu ke gudang distributor dan selanjutnya nanti pihak distributor akan menyalurkan dalam jumlah yang lebih kecil kepada retail outlet (pengecer) atau customer (konsumen) (Chopra, 2010).

Melihat pentingnya peran distribusi dalam Manajemen Rantai Pasok, maka perlu pembuatan jadwal distribusi yang optimal karena tentu setiap distributor memiliki batasan kapasitas dalam mengirimkan barang per periode, sedangkan jumlah dan jenis barang yang akan dikirimkan serta jumlah pasar atau konsumen tujuan jumlahnya juga banyak. Dengan adanya penjadwalan yang tepat, maka permintaan dari pasar atau konsumen akan dapat terpenuhi dan secara biaya operasional bagi distributor akan menjadi lebih efisien (Singh. 2014).

Vehicle Routing Problem merupakan permasalahan dalam sistem distribusi di mana tujuanya adalah membuat suatu rute optimal untuk sejumlah kendaraan yang diketahui kapasitasnya, sehingga mampu memenuhi permintaan customer dengan posisi lokasi dan jumlah permintaan (demand) yang telah diketahui. Tujuan Vehicle Routing Problem antara lain adalah (Toth \& Vigo, 2011) :

a) Meminimumkan ongkos perjalanan secara keseluruhan yang ditentukan oleh keseluruhan jarak yang ditempuh dan jumlah kendaraan yang digunakan

b) Menyeimbangkan rute untuk waktu perjalanan dan muatan (kapasitas) kendaraan

c) Meminimumkan jumlah kendaraan yang akan digunakan untuk melayani semua konsumen

d) Menghindari keterlambatan pengiriman kebutuhan (pesanan atau permintaan) konsumen sehingga tujuan minimalkan potensi keluhan konsumen dapat tercapai

Istilah konsumen yang digunakan dalam Vehicle Routing Problem menunjukkan pemberhentian untuk mengantar barang. Dalam konsep ini setiap konsumen hanya diantar oleh satu kendaraan saja. Tentunya kendaraan tersebut harus memiliki kapasitas untuk dapat mengantar barang sejumlah pesanan atau permintaan sejumlah konsumen sesuai rute yang dilakukan. Ilustrasi Vehicle Routing Problem dapat dilihat pada gambar berikut

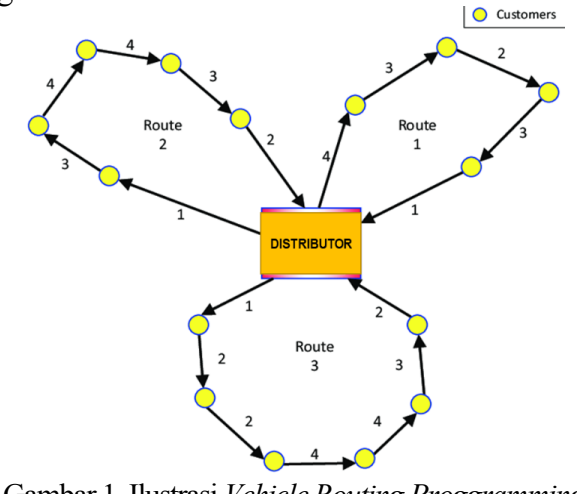

Gambar 1. Ilustrasi Vehicle Routing Proggramming 


\section{Studi Lapangan}

Peninjauan dilaksanakan untuk mendapatkan data rata-rata demand pasar kecamatan dan jarak antar lokasi pasar kecamatan

\section{Pengumpulan Data}

Dilakukan pengumpulan data jumlah rata-rata pengiriman produk ke setiap lokasi pasar. Selanjutnya dilakukan pengambilan sampel penjadwalan distribusi manual yang biasa dilakukan perusahaan lokasi penelitian dan menghitung biaya distribusinya (dengan gambaran satuan kilometer jarak). Untuk membuat dilakukan proyeksi peta Bojonegoro yang didekati dengan ukuran koordinat $\mathrm{x}$ dan $\mathrm{y}$.

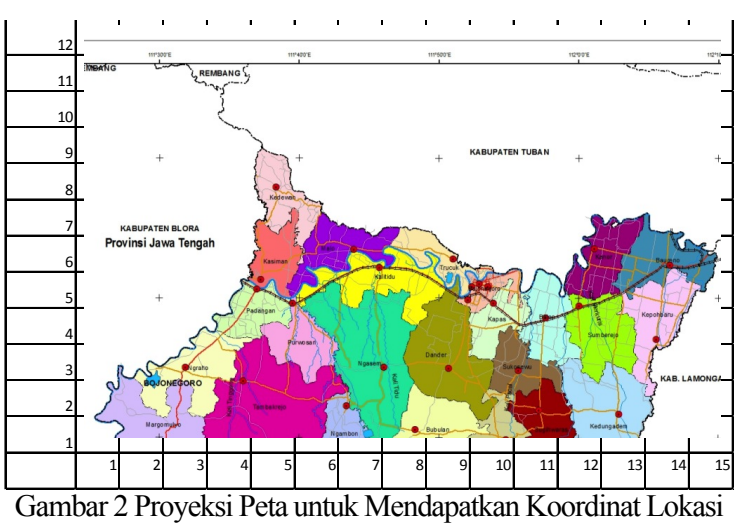

Data koordinat tersebut akan diolah menjadi data jarak yang menjadi representasi biaya transportasi dalam distribusi barang. Selanjutnya data yang diperlukan adalah data mengenai kebutuhan perusahaan distributor sebagai berikut :

1. Pengiriman dilakukan selama 5 (lima) hari kerja yaitu Senin sampai dengan Jumat

2. Batasan kapasitas kendaraan adalah 700 karton muatan

3. Setidaknya dalam satu hari harus ada 3 (tiga) pasar kecamatan yang dikirim produknya.

Hasil pengumpulan data jarak dan data permintaan pasar tujuan pengiriman distribusi adalah sebagai berikut (tabel 1):

\section{Perancangan Model Matematis}

Permodelan ini dibuat untuk menerjemahkan permasalahan, tujuan penelitian serta batasan keadaan permasalahan ke dalam bentuk model matematis.

\section{Input}

$d_{i}=$ permintaan pasar kecamatan $-i$

$c_{i j}=$ kapasitas rute atau kendaraan- $j$ untuk membawa barang ke rute pasar- $i$

$f_{i j}=$ jarak rute yang dilalui- $j$ untuk memenuhi permintaan daerah- $i$

Tabel 1. Pengolahan Data Jarak antar Pasar Kecamatan dan Jumlah Permintaan

\begin{tabular}{|c|c|c|c|c|c|c|c|c|c|}
\hline \multicolumn{2}{|c|}{ Koordinat } & \multirow[t]{2}{*}{ No } & \multirow[t]{2}{*}{ Pasar Kecamatan } & \multicolumn{5}{|c|}{ Jarak antar Pasar } & \multirow[t]{2}{*}{ Demand Produk } \\
\hline $\mathbf{x}$ & $\mathbf{y}$ & & & 1 & 2 & 3 & 4 & 5 & \\
\hline 10 & 7 & 1 & Kapas & 0 & 8 & 2 & 13 & 13 & 250 \\
\hline 8 & 9 & 2 & Bojonegoro & 8 & 0 & 10 & 1 & 41 & 220 \\
\hline 9 & 6 & 3 & Dander & 2 & 10 & 0 & 13 & 13 & 180 \\
\hline 7 & 9 & 4 & Kalitidu & 13 & 1 & 13 & 0 & 50 & 160 \\
\hline 12 & 4 & 5 & Kedungadem & 13 & 41 & 13 & 50 & 0 & 155 \\
\hline 6 & 6 & 6 & Malo & 17 & 13 & 9 & 10 & 40 & 130 \\
\hline 7 & 11 & 7 & Balen & 25 & 5 & 29 & 4 & 74 & 270 \\
\hline 2 & 4 & 8 & Margomulyo & 73 & 61 & 53 & 50 & 100 & 100 \\
\hline 2 & 6 & 9 & Ngraho & 65 & 45 & 49 & 34 & 104 & 95 \\
\hline 4 & 8 & 10 & Padangan & 37 & 17 & 29 & 10 & 80 & 95 \\
\hline 14 & 9 & 11 & Baureno & 20 & 36 & 34 & 49 & 29 & 220 \\
\hline 6 & 3 & 12 & Sekar & 32 & 40 & 18 & 37 & 37 & 80 \\
\hline 11 & 4 & 13 & Sugihwaras & 10 & 34 & 8 & 41 & 1 & 105 \\
\hline 8 & 12 & 14 & Sumberejo & 29 & 9 & 37 & 10 & 80 & 260 \\
\hline 10 & 6 & 15 & Tambakrejo & 1 & 13 & 1 & 18 & 8 & 180 \\
\hline
\end{tabular}

\section{Variabel Keputusan}

$X_{i j}=\left\{\begin{array}{l}1 \\ 0\end{array}\right.$ kendaraan- $j$ akan mengirim barang ke rute pasar- $i$ bila tidak
Minimasi

$$
\sum_{j} d_{i} \cdot f_{i j} \cdot X_{i j}
$$

Kendala fungsi

$$
\sum_{j} X_{i j}=1 \quad \forall i
$$




$$
\begin{array}{ll}
\sum_{i} X_{i j} \leq c_{i j} & \forall j \\
X_{i j}=0,1 & \\
\sum_{i} X_{i j} \geq 3 & \forall i
\end{array}
$$

Fungsi tujuan (2) bertujuan meminimasi biaya total yang ditimbulkan dari pengiriman ke semua pasar atau tujuan permintaan atau dengan kata lain biaya total yang timbul dari pengiriman barang. Selanjutnya fungsi kendala (3) menjamin bahwa semua pasar akan terpasok kebutuhannya, sedangkan fungsi kendala (4) menjamin bahwa distributor mampu mengirim barang atau memenuhi permintaan sesuai pesanan pasar. Kendala (5) adalah pemilihan hasil apakah pasar dikirim (angka 1) atau tidak dikirim (angka 0) pada rute pengiriman. Untuk fungsi kendala (6) adalah membatasi jumlah pasar yang dikirim pada setiap rute. Dengan memodelkan permasalahan pada penelitian ke dalam algoritma ILP diharapkan akan mampu mencapai solusi optimal dalam penjadwalan distribusi perusahaan.

\section{Pengumpulan Data}

Permodelan tersebut selanjutnya dimodelkan dalam bentuk slot di Ms. Excel

\begin{tabular}{|c|c|c|c|c|c|c|c|}
\hline 4 & $\mathrm{Y}$ & z & AA & $A B$ & $A C$ & $A D$ & $\mathrm{AE}$ \\
\hline 23 & No & Pasar Kecamatan & 1 & 2 & 3 & 4 & 5 \\
\hline 24 & 1 & Balen & 0 & 0 & 0 & 0 & 0 \\
\hline 25 & 2 & Baureno & 0 & 0 & 0 & 0 & 0 \\
\hline 26 & 3 & Bojonegoro & 0 & 0 & 0 & 0 & 0 \\
\hline 27 & 4 & Dander & 0 & 0 & 0 & 0 & 0 \\
\hline 28 & 5 & Kalitidu & 0 & 0 & 0 & 0 & 0 \\
\hline 29 & 6 & Kapas & 0 & 0 & 0 & 0 & 0 \\
\hline 30 & 7 & Kedungadem & 0 & 0 & 0 & 0 & 0 \\
\hline 31 & 8 & Malo & 0 & 0 & 0 & 0 & 0 \\
\hline 32 & 9 & Margomulyo & 0 & 0 & 0 & 0 & 0 \\
\hline 33 & 10 & Ngraho & 0 & 0 & 0 & 0 & 0 \\
\hline 34 & 11 & Padangan & 0 & 0 & 0 & 0 & 0 \\
\hline 35 & 12 & Sekar & 0 & 0 & 0 & 0 & 0 \\
\hline 36 & 13 & Sugihwaras & 0 & 0 & 0 & 0 & 0 \\
\hline 37 & 14 & Sumberejo & 0 & 0 & 0 & 0 & 0 \\
\hline 38 & 15 & Tambakrejo & 0 & 0 & 0 & 0 & 0 \\
\hline 39 & & $\begin{array}{l}\text { TOTAL MUATAN } \\
\text { RUTE }\end{array}$ & 0 & 0 & 0 & 0 & 0 \\
\hline 40 & & Maksimum & $<=$ & $<=$ & $<=$ & $<=$ & $<=$ \\
\hline 41 & & Muatan & 700 & 700 & 700 & 700 & 700 \\
\hline
\end{tabular}

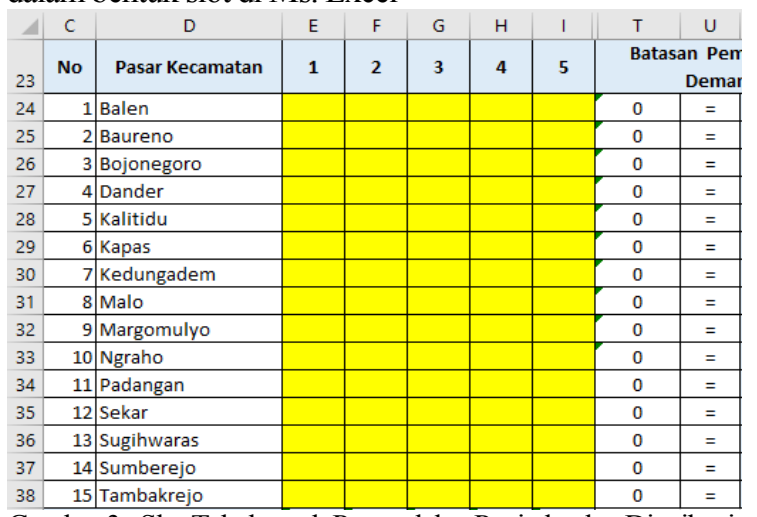

Gambar 3. Slot Tabel untuk Permodelan Penjadwalan Distribusi pada Ms. Excel dan Batasan Pemenuhan Demand
Gambar 4. Slot Tabel untuk Batasan Kapasitas Muatan Rute Pengolahan Data

Tahap selanjutnya adalah memasukkan formulanya ke dalam add-ins Solver sebagai berikut :

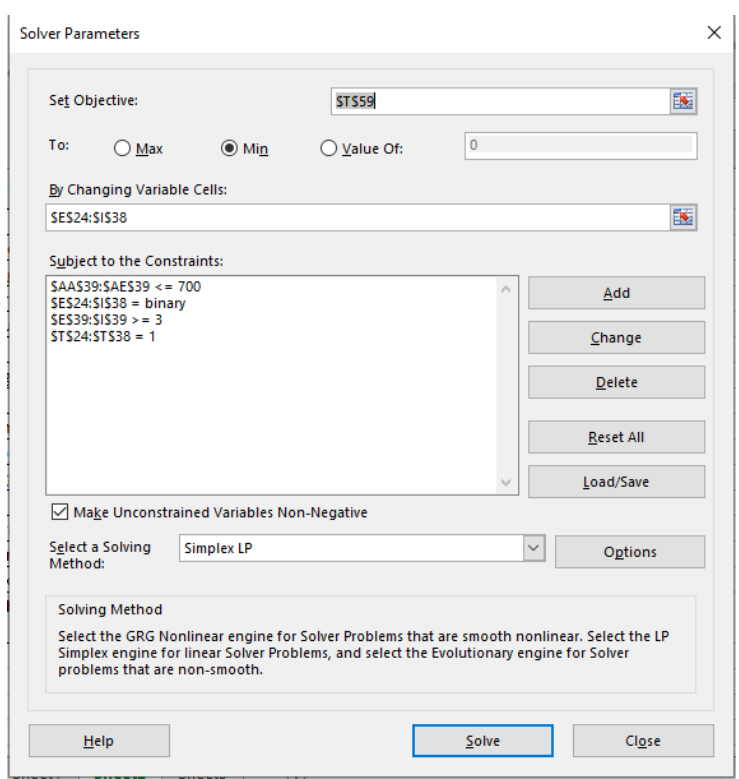

Gambar 5. Input Permodelan pada add-ins Solver

Selanjutnya hasil dari running pada add-ins Solver dianalisis pada sub bab berikutnya.

\section{Hasil dan Pembahasan}

Dari hasil pengolahan data dihasilkan bahwa fungsi dapat mencapai optimal dengan hasil sebagai berikut. 


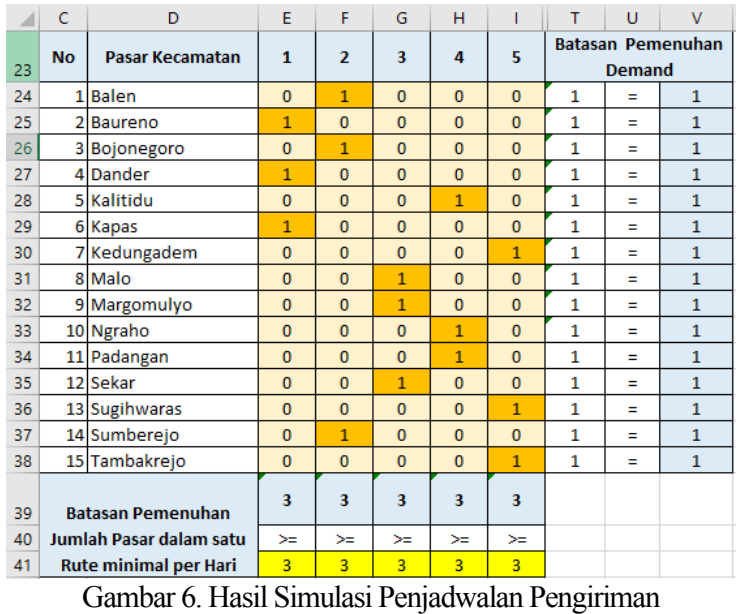

Dari tabel tersebut dapat dilihat bahwa penjadwalan akan menjadi seperti berikut.

Senin : Baureno, Dander, Kapas

Selasa : Balen, Bojonegoro, Sumberrejo

Rabu : Malo, Margomulyo, Sekar

Kamis : Kalitidu, Ngraho, Padangan

Jumat : Kedungadem, Sugihwaras, Tambakrejo

Untuk mengecek apakah semua kendala (batasan) terpenuhi, maka pengecekan dapat dilihat pada tabel pemenuhan kendala. Pada data yang diolah, berikut adalah hasil pengecekan kendala (batasan) kapasitas kendaraan.

\begin{tabular}{|c|c|c|c|c|c|c|}
\hline Y & z & AA & $A B$ & $A C$ & $A D$ & $\mathrm{AE}$ \\
\hline No & Pasar Kecamatan & 1 & 2 & 3 & 4 & 5 \\
\hline 1 & Balen & 0 & 250 & 0 & 0 & 0 \\
\hline 2 & Baureno & 220 & 0 & 0 & 0 & 0 \\
\hline 3 & Bojonegoro & 0 & 180 & 0 & 0 & 0 \\
\hline 4 & Dander & 160 & 0 & 0 & 0 & 0 \\
\hline 5 & Kalitidu & 0 & 0 & 0 & 155 & 0 \\
\hline 6 & Kapas & 130 & 0 & 0 & 0 & 0 \\
\hline 7 & Kedungadem & 0 & 0 & 0 & 0 & 270 \\
\hline 8 & Malo & 0 & 0 & 100 & 0 & 0 \\
\hline 9 & Margomulyo & 0 & 0 & 95 & 0 & 0 \\
\hline 10 & Ngraho & 0 & 0 & 0 & 95 & 0 \\
\hline 11 & Padangan & 0 & 0 & 0 & 220 & 0 \\
\hline 12 & Sekar & 0 & 0 & 80 & 0 & 0 \\
\hline 13 & Sugihwaras & 0 & 0 & 0 & 0 & 105 \\
\hline 14 & Sumberejo & 0 & 260 & 0 & 0 & 0 \\
\hline 15 & Tambakrejo & 0 & 0 & 0 & 0 & 180 \\
\hline & $\begin{array}{l}\text { TOTAL MUATAN } \\
\text { RUTE }\end{array}$ & 510 & 690 & 275 & 470 & 555 \\
\hline & Maksimum & $<=$ & $<=$ & $<=$ & $<=$ & $<=$ \\
\hline & Muatan & 700 & 700 & 700 & 700 & 700 \\
\hline
\end{tabular}

Gambar 7. Pemenuhan Kendala Kapasitas Muatan Kendaraan

Hasil tersebut menunjukkan bahwa pengiriman pada hari pertama sampai kelima tidak menyalahi batas maksimum kendaraan pengangkut barang (kurang dari 700 satuan)

Sedangkan untuk pengecekan kendala pemenuhan demand dan jumlah rute ditampakkan pada Gambar 2 menunjukkan bahwa setiap pasar terjamin pengirimannya atau terpenuhi permintaannya (ditunjukkan bahwa total binary adalah 1 atau terkirim). Sedangkan untuk rute dalam sehari juga terpenuhi yaitu minimal kendaraan (rute) pengiriman mampu melewati 3 (tiga) pasar kecamatan.

Pada Gambar 6 bawah ini berfungsi untuk menghitung total jarak yang harus ditempuh setiap hari atau dalam suatu rute. Pengecekan bertujuan supaya jarak total per rute adalah minimum.

Hasil pengolahan data di atas menunjukkan bahwa permodelan matematis dengan Integer Linear Proggraming dapat digunakan untuk menyelesaikan Vehicle Routing Problem yang terjadi pada perusahaan. Adanya permodelan memudahkan untuk simulasi keadaan nyata ke dalam perhitungan. Dengan bantuan tools add-ins Solver pada Ms. Excel juga membantu model untuk dapat diselesaikan dengan cepat.

\begin{tabular}{|c|c|c|c|c|c|c|c|c|}
\hline 4 & C & D & $E$ & $\mathrm{~F}$ & G & $\mathrm{H}$ & 1 & $\mathrm{~T}$ \\
\hline 43 & No & Pasar Kecamatan & 1 & 2 & 3 & 4 & 5 & \\
\hline 44 & 1 & Balen & 0 & 5 & 0 & 0 & 0 & \\
\hline 45 & 2 & Baureno & 20 & 0 & 0 & 0 & 0 & \\
\hline 46 & 3 & Bojonegoro & 0 & 0 & 0 & 0 & 0 & \\
\hline 47 & 4 & Dander & 2 & 0 & 0 & 0 & 0 & \\
\hline 48 & 5 & Kalitidu & 0 & 0 & 0 & 0 & 0 & \\
\hline 49 & 6 & Kapas & 0 & 0 & 0 & 0 & 0 & \\
\hline 50 & 7 & Kedungadem & 0 & 0 & 0 & 0 & 0 & \\
\hline 51 & 8 & Malo & 0 & 0 & 9 & 0 & 0 & \\
\hline 52. & 9 & Margomulyo & 0 & 0 & 53 & 0 & 0 & \\
\hline 53. & 10 & Ngraho & 0 & 0 & 0 & 34 & 0 & \\
\hline 54 & 11 & Padangan & 0 & 0 & 0 & 10 & 0 & \\
\hline 55 & 12 & Sekar & 0 & 0 & 18 & 0 & 0 & \\
\hline 56 & 13 & Sugihwaras & 0 & 0 & 0 & 0 & 1 & \\
\hline 57 & 14 & Sumberejo & 0 & 9 & 0 & 0 & 0 & \\
\hline 58 & 15 & Tambakrejo & 0 & 0 & 0 & 0 & 8 & \\
\hline 59 & & $\begin{array}{l}\text { JUMLAH BIAYA } \\
\text { (JARAK RUTE) }\end{array}$ & 22 & 14 & 80 & 44 & 9 & 169 \\
\hline 60 & & & & ונד & VMI & MAS & RAI & \\
\hline
\end{tabular}

Gambar 8. Pengecekan Total Jarak (Biaya) Pengiriman

\section{Kesimpulan}

Dari penelitian yang dilakukan maka didapatkan kesimpulan sebagai berikut :

a) Permasalahan Vehicle Routing Problem dapat didekati dengan algoritma Integer Linear Proggramming

b) Permodelan dengan bantuan tool add-ins Solver pada Ms. Excel dapat membantu menyelesaikan fungsi permasalahan penjadwalan pengiriman barang

c) Penjadwalan pengiriman barang yang optimal akan menghemat biaya pengiriman dari segi jarak (ongkos transportasi) dan menghindari keterlambatan barang di tangan konsumen 


\section{Daftar Pustaka}

Chopra, Sunil dan Peter Meindl. 2010. Supply Chain Management: Strategy, Planning, and Operations. New Jersey: Prentice Hall.

Fisher M. 1995. Vehicle Routing. Handbook of Operational Research Management Science. 8:131.

Indrajit, R. E., \& Djokopranoto, R. 2003. Manajemen Persediaan, Barang Umum dan Suku Cadang untuk Pemeliharaan dan Operasi. Jakarta: Grasindo

P. Toth and D. Vigo, The Vehicle Routing Problem. Soc. for Industrial and Applied Math, Philadelphia, 2001.

Pop, Petrica Claudiu, et al. 2011. Heuristic Algorithms for Solving the Generalized Vehicle Routing Problem. International Journal of Computers Communications \& Control 6.1 : 158165

Singh, Amol. 2014. Supplier Evaluation and Demand Allocation among Suppliers in a Supply Chain. Journal of Purchasing and Supply Management 20 (3). Elsevier: 167-76. 